\title{
Screening and identification of novel biologically active
}

\section{natural compounds [version 1; peer review: 2 approved]}

\section{David Newman}

Newman Consulting LLC, Wayne, PA, USA
1 First published: 05 Jun 2017, 6(F1000 Faculty Rev):783

https://doi.org/10.12688/f1000research.11221.1

Latest published: 05 Jun 2017, 6(F1000 Faculty Rev):783

https://doi.org/10.12688/f1000research.11221.1

\section{Abstract}

With the advent of very rapid and cheap genome analyses and the linkage of these plus microbial metabolomics to potential compound structures came the realization that there was an immense sea of novel agents to be mined and tested. In addition, it is now recognized that there is significant microbial involvement in many natural products isolated from "nominally non-microbial sources".

This short review covers the current screening methods that have evolved and one might even be tempted to say "devolved" in light of the realization that target-based screens had problems when the products entered clinical testing, with off-target effects being the major ones. Modern systems include, but are not limited to, screening in cell lines utilizing very modern techniques (a high content screen) that are designed to show interactions within cells when treated with an "agent". The underlying principle(s) used in such systems dated back to unpublished attempts in the very early 1980 s by the pharmaceutical industry to show toxic interactions within animal cells by using automated light microscopy. Though somewhat successful, the technology was not adequate for any significant commercialization. Somewhat later, mammalian cell lines that were "genetically modified" to alter signal transduction cascades, either up or down, and frequently linked to luciferase readouts, were then employed in a 96-well format. In the case of microbes, specific resistance parameters were induced in isogenic cell lines from approximately the mid-1970s. In the latter two cases, comparisons against parent and sibling cell lines were used in order that a rapid determination of potential natural product "hits" could be made. Obviously, all of these assay systems could also be, and were, used for synthetic molecules.

These methods and their results have led to a change in what the term "screening for bioactivity" means. In practice, versions of phenotypic screening are returning, but in a dramatically different scientific environment from the 1970s, as I hope to demonstrate in the short article that follows.

\section{Keywords}

natural compounds, natural products, screening, bioactive materials

\author{
Open Peer Review \\ Approval Status \\ 1 \\ 2 \\ version 1 \\ 05 Jun 2017 \\ Faculty Reviews are review articles written by the \\ prestigious Members of Faculty Opinions. The \\ articles are commissioned and peer reviewed \\ before publication to ensure that the final, \\ published version is comprehensive and \\ accessible. The reviewers who approved the final \\ version are listed with their names and \\ affiliations. \\ 1. Roger G. Linington, University of California, \\ Santa Cruz, USA \\ 2. Rolf Müller, Saarland University, \\ Saarbrücken, Germany
}

Any comments on the article can be found at the end of the article. 
Corresponding author: David Newman (djnewman664@verizon.net)

Competing interests: The author declares that he has no competing interests.

Grant information: The author(s) declared that no grants were involved in supporting this work.

Copyright: $\odot 2017$ Newman D. This is an open access article distributed under the terms of the Creative Commons Attribution License, which permits unrestricted use, distribution, and reproduction in any medium, provided the original work is properly cited.

How to cite this article: Newman D. Screening and identification of novel biologically active natural compounds [version 1; peer review: 2 approved] F1000Research 2017, 6(F1000 Faculty Rev):783 https://doi.org/10.12688/f1000research.11221.1

First published: 05 Jun 2017, 6(F1000 Faculty Rev):783 https://doi.org/10.12688/f1000research.11221.1 


\section{Introduction}

Over the last 40 or so years, bioactive natural product discovery and development has moved from what was known colloquially in the trade as "grind and find techniques", also termed "determining the phytochemistry of the plant", to the use of very advanced analytical, genomic, metabolomic, and informatic techniques together with high throughput and/or "high content screening".

In the days when the author was active in an industrial laboratory as a bench scientist, mainly in antibiotic discovery (late 1960s through the early 1980s), the methods always involved the screening of compounds or extracts against microbial cells, usually a relatively safe surrogate, such as the standard FDA strain of Staphylococcus aureus known as "209P", a common Escherichia coli strain, and a suitable Candida albicans strain, all designed to show activity that could then be followed in a bioactivity-driven isolation format. During this time frame, "crude pre-fractionation systems" were utilized that consisted of adsorption or desorption through different ion-exchange systems, macro-reticular resins (based on XADs), silica gel, and alumina columns, sometimes independently, other times in series. Since these columns were handmade using Pasteur pipettes (the "Sep-Pak systems" were well in the future) and highperformance liquid chromatography (HPLC) was unknown until the late 1970s, the throughput was slow but effective in determining some of the potential chemical classes of antibiotics, aminoglycosides for example, that were in the crude extracts. Semi-purified extracts from these processes would then be tested in vivo in suitable mouse models of infection. Similar techniques were also used by scientists (including the author) when investigating antitumor activities in crude extracts of marine invertebrates and an occasional plant extract. Then, a simple mouse leukemia (L1210 or P388), or at times $\mathrm{KB}$ or HeLa (confluent mammalian), cell line was used to follow biological activities, followed by in vivo studies in both situations in either syngeneic (usually at the time) or SCID or $\mathrm{NuNu}$ mice if the facilities were available.

In contrast, most of the investigators who were not connected to the then-large-scale program run by the US National Cancer Institute (mid-1960s to 1981), and who were using plants as a source, would conduct isolation and purification of compounds from a plant extract (determining the phytochemistry of the source) and then, once the compound had been identified, might have a proportion of the pure materials tested in any "available assay", hence the use of the soubriquet "grind and find" for this process. Even today, this system is still in place, mainly for plant-derived materials, in countries where the scientific infrastructure is not conducive to cell-line and/or animal screening owing mainly to the cost of the infrastructure required to maintain such facilities.

To perhaps the chagrin of a considerable number of natural product chemists, and in particular botanists and marine biologists, it is now becoming evident that molecules that have very significant biological activities from a pharmaceutical perspective are often not produced by the organism from which they were isolated but are the product of either microbes that are "in, on, or around" the source organism, or are perhaps the product of "chemical talk between organisms", with at times the nominal producer being only a "container" for the single-celled organism/organisms that is/are the source.

What I hope to demonstrate is how the interplay of genomics and metabolomics coupled to mass spectroscopy $\left(\mathrm{MS}^{\mathrm{n}}\right)$ and informatics has led to what can be classified as a revolution in both screening and isolation, with novel screens (or not as will be seen later) coupled to the very rapid identification of compounds. In some respects, a very complex "grind and find" operation, in others a very sophisticated analytical screening, followed by the isolation of active entities using a multiplex approach.

The unifying principle might be, if I am allowed a little humor, "what you isolate may not be produced by what you thought was the source", and I will show that, as a result, Mother Nature still has many tricks to show us.

\section{Screening secondary metabolites: nominally from all sources (microbe, marine invertebrate, and plant) Preamble}

What I hope to do is, by utilizing the data from a series of published research papers and reviews from 2012 to date (together with some earlier papers that demonstrated the necessary science), show that the term "screening for bioactive agents" covers a number of related approaches, with the advances in the rapid identification of secondary metabolites over the same time period being due to one major method, that of $\mathrm{MS}^{\mathrm{n}}$, or multiplexed mass spectral approaches, with the use of HPLC or, in its absence, and as shown later, nuclear magnetic resonance (NMR) profiling of enriched fractions. The utilization of these techniques coupled to very rapid next-generation sequencing of gene clusters and/or total genome sequencing and significant advances in informatic analyses of the data obtained have caused a major paradigm shift in "the concept of screening".

A major emphasis, as might be evident from the introductory comments, is on microbes, both currently cultivatable and those that are not yet able to be cultivated. The use of cultivatable microbes is obvious, but one may ask, how on earth can you utilize the asyet-uncultivated organisms? I will show how this has been done successfully and the extremely interesting findings that have come from such efforts.

\section{Screening methods and perceived current practice}

Anyone who reads the literature related to the discovery of bioactive materials, irrespective of whether the sources are natural products, modified natural products, or synthetic compounds, has realized that, over the last 25-30 years, the (perceived) paradigm changed from phenotypic screening (usually cell or animal based) to the use of isolated "targets". The reasons for this change are quite simple but not often mentioned. The "collision" of the invention of the 96well plate, the rise of recombinant DNA technologies, and access to cheap and simple computing platforms (the PC) permitted the rapid production of targets (enzymes or proteins), their "interrogation" by semi-automated to automated systems, and the analyses of results in a short time period. 
This led to the realization that the numbers of available chemical compounds were much too low, and since the screens were run in campaign-mode, the time frame, usually less than 3 months for a given screen, was totally unsuitable for the screening of other than pure natural products in the late 1980s to mid-1990s. This lack of compounds to test led to the initial rise of combinatorial chemistry, which promised to solve the supply and any intellectual property problems, since the compounds produced were only in a particular laboratory or company. Literally millions of compounds (pure and semi-pure) were screened in massive numbers of screens, and compounds were identified as "hits or leads", but miniscule numbers actually reached preclinical status and then clinical trials.

In practice, if one looks at the analyses of sources of drugs since 1981 to 2014, there are perhaps three approved drugs worldwide that are de novo combinatorial discoveries, with one being discovered by the use of fragment techniques on targets ${ }^{1}$. Combinatorial chemistry is magnificent for the development of an existing lead, but not for de novo discovery. Further examples of the problems with drugs approved from the use of target-based screens (in the area of anticancer drugs) are their side effects. As Fabbro (the biologist behind Gleevec ${ }^{\circledR}$ ) explained in $2014^{2}$ and $2015^{3}$, people forgot (or did not realize) that multiple types of kinases are not only present in cancer cells but also essential components of all cell metabolism.

To add to the confusion surrounding "target choices", a paper published in late March 2017 by a group from Cold Spring Harbor ${ }^{4}$ throws doubt upon a choice of a particular kinase (MELK) in triple negative breast cancer. In this paper, MELK, the target of two drugs thought to be MELK inhibitors from kinase testing and currently in clinical trials, was shown not to be the target by use of CRISPR/ Cas9 technology, even though the original target was "correlated with RNAi inhibition". By knocking out the "MELK target" and still demonstrating excellent cell growth inhibition, the target of these clinical candidates is now open to question. Thus, in this particular case, target-based screening is "debatable". How many more such "problems" are yet to be found using this technology is now an open question.

A very interesting recent review was the thorough analysis done of all drugs approved by the US FDA for the treatment of cancer between 1999 and 2013 by Moffat et al. ${ }^{5}$ This review built on the earlier report by Swinney and Anthony, who in 2011 demonstrated that, of the 183 small molecule drugs approved across diseases between 1999 and 2008, 58 (32\%) were from phenotypic screens, and if one considered new entities that were "first in class", then 28 of the 50 were from phenotypic screens and 17 were from targetbased systems ${ }^{6}$.

Do the figures in the paragraph above mean that one should go back to phenotypic screening or continue with targeted methods? There is no one answer to this question, but what has been occurring over the last 7-plus years, because of the significant advances mentioned in the opening paragraph of the preamble, is that a very up-to-date version of "grind and find" has now effectively taken over the initial screening systems, at least in the case of microbial secondary metabolites.

Discussions centered around such organisms will be the major focus of the rest of this review for the relatively simple reasons that a large percentage of all marine invertebrate-sourced natural products are the result of the interplay between microbes and their hosts. In addition, it is now becoming evident that a similar relationship may occur with a significant number of plants, in particular with their fungal endophytes, and there are now many examples of insects using microbes as sources of defensive metabolites?

\section{Modern versions of "grind and find" and their use in screening}

Application of single-cell genome interrogation to natural product structures

More than 20 years ago, the biotech company Diversa built upon some earlier research by a smaller biotech company, One Cell, where environmental microbes were diluted out and effectively suspended in a single drop of medium. This system allowed the growth of some previously uncultivated microbes but was not further followed up once Diversa folded. Recently, a Japanese group published a method using water-in-oil droplets to ferment such organisms but either were unaware of the much earlier work or did not locate any relevant references to it $^{8}$. However, they did reference a 2014 paper in Nature ${ }^{9}$ that demonstrated not the fermentation of as-yet-uncultivated microbes but the isolation of single cells and subsequent DNA amplification that permitted the identification of the biosynthetic pathways of what were thought to be, up to that time, marine-sponge-derived bioactive metabolites.

In 2014, the Piel group at the ETH in Zurich published the paper mentioned above, which effectively revolutionized the understanding of the source of over 30 bioactive marine spongesourced secondary metabolites ${ }^{9}$. The sponge Theonella swinhoei $\mathrm{Y}$ (Y for "yellow variant") was a well-known producer of bioactive compounds with over 30 bioactive structures determined over the years. These compounds came from a combination of classical isolation and then biological activity determination and the use of bioactivity-driven isolation depending upon the compound.

In this paper, the group demonstrated, by the isolation of single bacterial cells from the whole sponge macerate, that the previously unknown and currently uncultivated microbe had the genomic potential to produce the widely disparate structures previously found, including the very potent agent onnamide (Figure 1, [1]), a pederin-based (Figure 1, [2]) molecule originally found in the Brazilian blister beetle. The story of the work performed over more than 30 years that led to the identification of pederin as a microbial product was covered in a recent publication ${ }^{7}$. The techniques of DNA amplification from a single microbe through to the determination of biosynthetic methods are now being applied to other marine-derived secondary metabolites, and two recent papers from the Piel group should be consulted for current information ${ }^{10,11}$. However, it should be pointed out at this stage that this is only the 


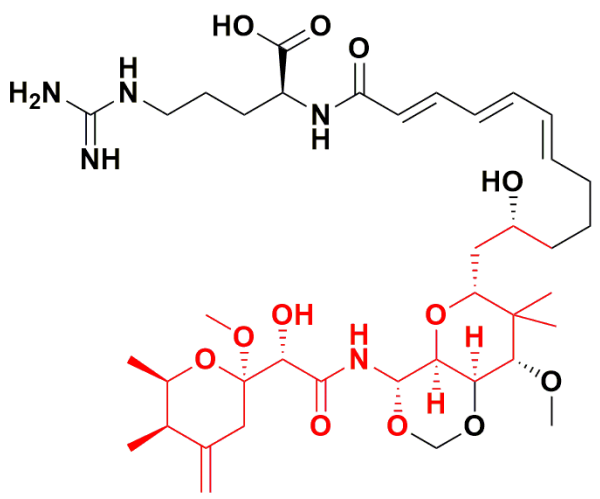

1. Onnamide Red $=$ Pederin Skeleton

Figure 1. Onnamide and Pederin. Onnamide and Pederin.

"tip of the iceberg" as far as any production system is concerned. Although it might be feasible to use Theonella as a host in aquacultural production, as was done by the New Zealand group $^{12}$ in the 1990s to produce small quantities of halichondrin B, it will probably need to be transferred into a heterologous host in order to produce any metabolite from this discovery.

\section{Mass spectral in situ determination of secondary metabolites}

In 2009, Esquenazi et al. published a review of the techniques that could visualize the production of secondary metabolites in microbes during their growth phase and, in particular, demonstrated the utility of imaging $\mathrm{MS}^{\mathrm{n}}(\mathrm{IMS})^{13}$. This methodology permitted researchers to follow secondary metabolite production in bacterial cells by using the mass spectrum of the chosen metabolite as the sensor. In two later reviews in 2011, the Dorrestein group, of which Esquenazi was then a member, demonstrated that the technique was of significant import in determining the spatial production of metabolites and that one could also recognize the presence and production of novel metabolites ${ }^{14,15}$.

That this was not just a technique for demonstrating production at a single time point was shown in 2012, when Xu, working with other scientists at the Scripps Institute of Oceanography, used the technique to demonstrate the production of didemnin $\mathrm{B}^{16}$. This compound, prior to a single report in $2011^{17}$, was thought to be the product of an encrusting ascidian and was the first directly marinesourced compound to enter clinical trials as a potential antitumor agent. In the report from the Scripps group and their collaborators, the authors not only demonstrated the production of didemnin B but also, by growing the producing microbe on a suitable matrix that supported the use of IMS, were able to follow the time course of didemnin B production in the "fermentation" for the first time. The sequence of the production of "putative" intermediates leading to the final molecule, didemnin $\mathrm{B}$, in the biosynthetic pathway was determined directly, thus proving the proposed biosynthetic pathway $^{16}$.<smiles>C=C1C[C@](OC)([C@H](O)C(=O)N[C@H](OC)[C@H]2C[C@H](O)C(C)(C)[C@@H](C[C@@H](COC)OC)O2)O[C@H](C)[C@@H]1C</smiles>

\section{Pederin}

Linkage of mass spectroscopy and genetic sequences as primary screening systems

With the examples described above as proof of the utility of the technique, a substantial number of papers have been published over the last 4 years or so showing the capabilities of $\mathrm{MS}^{\mathrm{n}}$ as a screening tool either coupled to genomic sequences or recognizing the production of potential novel compounds before biological screening. Although the advent of next-generation sequencing permitted the identification of biosynthetic gene clusters, either as part of a full sequence determination or as isolated entities, a major stumbling block was in proving that a given gene cluster produced a metabolite of interest, though significant numbers of linkages were obtained, usually by comparative studies.

Thus, by linking mass spectral analyses to genomic sequencing, investigators could link the production and identification of a given series of molecules to a particular microbe and then frequently identify the potential genomic cluster. Doroghazi et al. in $2014^{18}$ published the initial results of an analysis of 830 actinomycete genomes that included 344 new total genomes and 412 gene clusters that were listed in GeneBank and produced known secondary metabolites. Using a significant number of computational tools, the data obtained were grouped into 4,122 gene cluster families (denoted as GCFs) containing 11,422 gene clusters. The clustering or metabolite production was validated in a significant number of instances by mass spectral analyses of the metabolites produced. What was also of interest were the numbers of natural product gene clusters found per taxonomic family, with the well-known families having averages around the lower 20s per genome analyzed. Does this mean no duplication across families? No, but the technique permits a rapid deconvolution in due course, particularly when coupled to the results of other techniques that will be discussed below.

In 2016, Henke and Kelleher published an excellent short review on the utility of $\mathrm{MS}^{\mathrm{n}}$ techniques to dereplicate compounds from microbes using a "structure-based approach" rather than a bioactivity-driven approach ${ }^{19}$. Effectively, $\mathrm{MS}^{\mathrm{n}}$ techniques came to the 
rescue of a "grind and find" process. In addition to this review, there were other significant reviews covering the use of these techniques that should also be consulted by interested readers. The limitation of length in this review means that discussion of these other papers covering the utility of this approach cannot be covered, but the following recent papers are well worth consulting ${ }^{20-28}$.

\section{Gene maps as leads to novel natural product bioactivities}

There are two databases that have the potential to help in the screening of both fractionated extracts (see next section for a discussion of such libraries) and pure compounds. The largest is the "connectivity map", also known as "cmap", located at the Broad Institute of MIT and Harvard in Cambridge, Massachusetts ${ }^{29}$. Quoting from their website at https://portals.broadinstitute.org/ $\mathrm{cmap} /$, the cmap "is a collection of genome-wide transcriptional expression data from cultured human cells treated with bioactive small molecules and simple pattern-matching algorithms that together enable the discovery of functional connections between drugs, genes and diseases through the transitory feature of common gene-expression changes". Although there do not seem to be any published results from screening of natural product extract libraries, there definitely is significant potential for future use.

However, a smaller database specifically designed to link natural product isolation, in this case from marine-sourced microbes, with notation of a possible mechanism of action was constructed by MacMillan and White at the University of Texas, Southwestern Medical Center. A recent paper has demonstrated its success in working with marine-derived natural products and leading to the identification of a novel AKT inhibitor ${ }^{30}$.

\section{Pre-fractionation of natural product libraries}

What has occurred in the last few years is the realization by natural product chemists and biologists that extracts from any natural product source are not generally amenable to high-throughput screening, particularly against enzymes/receptors. Though there have been recent reports of successful programs using the crude microbial extracts from the NCI microbial extract libraries ${ }^{31-33}$, their costs were significant and were paid for by some version of a grant or contract.

There are also potential problems involved in dereplication in any system that utilizes the same or a similar microbe in multiple media and growth conditions, which were part of the sources of the NCI microbial extract collection, where microbes could have been fermented in up to 12 different media conditions commencing in the late 1980s. This multiple media approach has been entitled OSMAC (one strain/many compounds) and is often ascribed to work reported in 1999 by Schiewe and Zeek ${ }^{34}$. This attribution is incorrect, although it has entered the literature since the process was first described from an academic aspect by Zahner in $1977^{35}$ and had been in general use in the antibiotic discovery programs in the pharmaceutical industry for at least 17 years prior to the Zahner paper. Since industry generally did not publish their techniques (the author was using such systems before 1970, and they had been in general use since the early 1960s), such information is not in the general literature, though the NCI contract conditions that led to their microbial collection were written by a retired microbiologist from Squibb and published in the mid-1980s specified just such an approach.

Thus, in order to reduce the problems associated with crude microbial extracts in particular, together with plant and marineinvertebrate extracts, scientists continued to think about how to optimize extracts for screening. The first formal publication from academia on the concept of pre-fractionation of crude extracts was probably the paper in 1999 by Schmid et al. from the Hans-Knoll Institute in Germany, quoting the use of Zymark SPE work stations for such fractionations ${ }^{36}$. Though perhaps the first academic link, the concept had been used in various ways in small and large companies for years before then. Small companies in the early 1990s, such as Xenova in the UK, used pre-fractionation with HPLC tracing. Earlier, as mentioned above, in the late 1970s, larger companies such as SK\&F (now GSK) used much cruder versions of the same concept owing to analytical limitations (personal observation by the author). From 2002 to 2008, companies such as Sequoia (specializing in plant-based materials from the Missouri Botanical Gardens) ${ }^{37}$, bioLeads $\mathrm{GMBH}^{38}$, and MerLion, specializing in microbial and marine invertebrate extracts ${ }^{39}$, together with Wyeth ${ }^{40}$ published their methodologies, with probably the first academic group to publish after the Hans-Knoll group mentioned earlier being the Ireland group at Utah in the later $2000 \mathrm{~s}^{41}$.

All of the fractionation methods used from the late 1990s were designed so that individual "wells or tubes" would in general contain only 3-10 compounds, and from the early 2000s analytical data on the pre-fractionated materials was obtained during the process $^{41-47}$. It should be noted, however, that the initial impetus for fractionation before assay came from industry or from groups that started in industry and then moved into academia (i.e. Quinn at Astra Zeneca and then Griffith University, and Butler at MerLion and then University of Queensland).

Although all have overlap in their coverage, the following three review articles are worthwhile extra reading on the pre-fractionation topic. The 2013 review by Henrich and Beutler includes the pre-fractionation techniques used at the NCI that utilize the NCI's Natural Products Repository ${ }^{44}$. The 2014 chapter on Marine Bioprospecting by Fenner and Gerwick covers the usage of marinederived extracts ${ }^{47}$, whilst the 2015 review by Gaudencio and Pereira covers the whole period from 1993 to mid-2015

\section{Utility of fractionated natural product libraries and NMR profiling}

Another instrumental technique that can be said to have "come of age" in screening processes is the use of NMR profiling of natural product extracts as a screening tool. The use of what could be termed "hyphenated-analytical systems including online NMR" in the initial profiling/screening of compounds as they eluted from (usually) HPLC systems has a relatively long history, with one of the first online NMR analyses of single compounds as a method of detection published 20 years ago ${ }^{49}$. 
The Eskitis group at Griffith University used their modification of pre-fractionation to analyze solid-state fermentation extracts of Streptomyces strains isolated from termite gut. These extracts were fractionated into lead-like enhanced (LLE) fractions using published methodology from their laboratories ${ }^{43}$. This process led to a dataset of 420 LLE fractions and each was subjected to NMR profiling, with the spectra being manually examined for the occurrence of unique chemical profiles. They were classified as non-repetitive or unique NMR resonances and then followed further dereplication by linking specific spectral types to the previously collected distinctive ESIMS ion peaks (these were collected during the LLE process). These processes enabled the identification of six new secondary metabolites in addition to five known metabolites ${ }^{50}$.

\section{Unbiased phenotypic screening with pure natural products in high content screens}

Two excellent papers were published in 2016 from the Quinn group in Australia demonstrating how to couple phenotypic screening against non-immortalized human olfactory neurosphere-derived (hONS) cells (primary cells derived from Parkinson's disease patients) with pure natural products using a high content screening system. The first screen covered isolated metabolites from marine sponges (Jaspis splendens) to prove that the overall system could function $^{51}$. The following screen then utilized a 500-plus pure compound set from the Nature Bank collection at Griffith University ${ }^{52}$. The results demonstrated that such a high content screen produced multiple possibilities for the identification of the interaction(s) with cellular organelles/protein interactions, being limited only by the specificity of the fluorescent probes used to demonstrate the responses.

To further demonstrate the potential of such high content screening, recently an excellent review covering almost all aspects of high content screening and its associated operations was published by a German group from the Helmholtz Centre in Braunschweig (the old GBF). This should be read in order to see the progression in techniques and technologies from 1997 to the end of $2015^{53}$.

\section{Metabolomics meets modern assay techniques}

In a review paper in $2015^{54}$, Kurita and Linington covered the various techniques that now permit results from high content screening of extracts to link phenotype and chemotype and, later that same year, published an excellent paper on what they call "compound activity mapping", which integrates high content biological screening and untargeted metabolomics to identify potential compounds with activity ${ }^{55}$. This article should also be read in conjunction with the comments above on "cmap" and "FuSiOn" databases.

Although most scientists working with microbes have tended to work with eubacteria, predominately actinobacteria, there are two groups who have worked in other taxa for many years: one with fungi, predominately Aspergillus species, and the other with myxobacteria.

In the case of fungi, although it is not yet feasible to survey the complete secondary metabolome of a single fungus, there is the potential for 80-100 putative biogenetic clusters to be recognized from full genome studies in Aspergillus strains ${ }^{56}$. In addition, the activation of cryptic clusters via epigenetic "tricks" also demonstrated further potential in these organisms ${ }^{57}$. As a result, their potential is really only just being recognized ${ }^{21,58-60}$.

In the case of the myxobacteria, which are predatory Gram-negative bacteria, just as in the case with the Keller group at the University of Wisconsin and Aspergillus, one research group, the Müller group in Germany (the lineal descendant of the Reichenbach and Höfle group at the then GBF in Braunschweig), are the pre-eminent investigators of secondary metabolites from this unusual taxon. In the last 4 years, they have published some excellent articles on this particular group of microbes, demonstrating their potential as sources of compounds with unusual structures and biological activities $^{61-64}$. In addition, what is relevant to the comments earlier about actual sources not being what they were thought to be, in 2015, the Müller group plus a group from Sanofi in Germany reported not only the isolation of bengamides (Figure 2 [3]; a series of compounds originally isolated from Jaspis sponges) from terrestrial myxobacteria but also the details of large-scale production and optimization of the base structure ${ }^{65}$. The initial report of production of the bengamides from a terrestrial microbe was in fact in a patent application from Sanofi-Aventis in 2003, with the patent's international filing date being in October $2004^{66}$. This demonstrates that the claim for the first report showing the material from a myxobacterial source from the Crews' group in California in $2012^{67}$, who had reported the marine-sourced bengamides many years previously, is not correct and emphasizes that the patent literature can hold very significant information that is often not checked by academic scientists. This taxon also produces the microsclerodermins (Figure 2, [4]), agents originally reported by Bewley et al. in 1994 from a lithistid sponge and then, just as in the case of the bengamides, reported by the Müller group in 2013 from a terrestrial myxobacteria ${ }^{68}$.

\section{Statistical tools for the interrogation of results}

Although the production of spectral data of all types is now a "relatively simple process" if one has the necessary resources, the conversion of such datasets into usable information, structures, linkage to targets etc. is a process that requires the use of multiple statistical tools, thus the processes are comparable to the use of "chemometrics" in chemical operations. Chemometrics is usually defined as "relating measurements on a chemical system or process to the state of the system via application of mathematical or statistical methods", the use of principal component analysis (PCA) being just one example of the tools available.

In order to link information from multiple sources to "screen" natural products, a number of groups, some referred to earlier, have used "chemometric methods" linked to biological datasets so that initial findings from one analytical system can relatively easily be used to link to previously identified compounds, biological targets, genomic sequences, and metabolomic datasets across taxa. The datasets used are not limited to just natural products but can, and do, cross into information derived from synthetic or semi-synthetic compounds that have reported biological activities. Recent examples are the articles (some referred to earlier) from the Dor- 


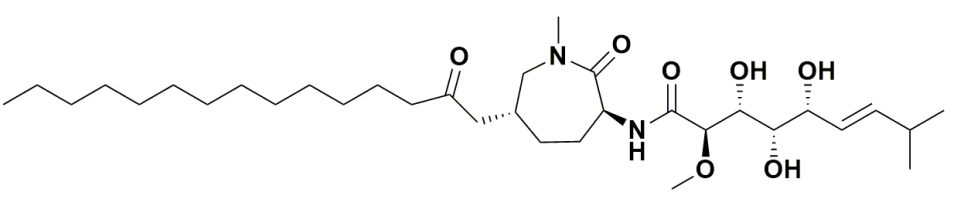

3. Bengamide $B$

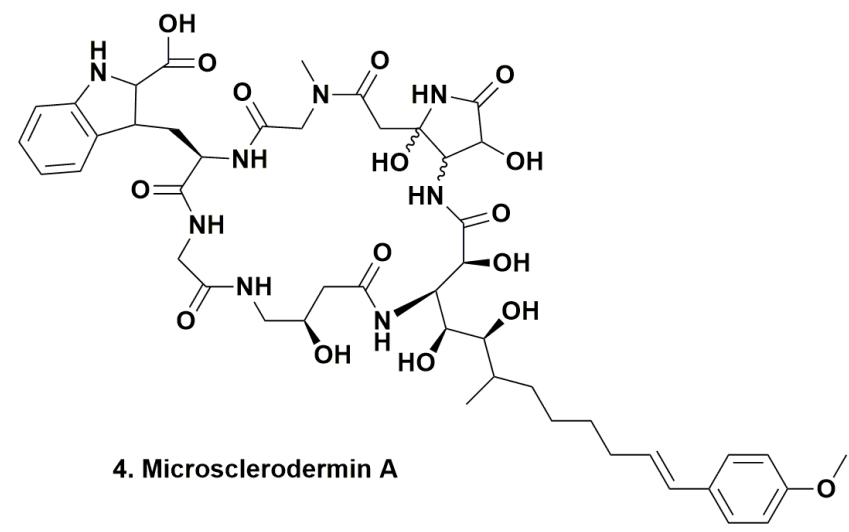

Figure 2. Bengamide B and Microsclerodermin A. Bengamide B and Microsclerodermin A.

restein group and collaborators ${ }^{22,24,69,70}$ and the Linington group and collaborators (also referred to earlier) ${ }^{55}$. In addition to these, recent papers that deal with the chemometric link are one by Humbeck and $\mathrm{Koch}^{71}$ and two papers from the Oberlies group ${ }^{72-73}$.

\section{Epigenetic modulation of source microbes}

An area that may well have significant relevance in the future is (in addition to "persuading" as-yet-uncultivated microbes to grow, thus enabling the use of the vast array of techniques that can be used in fermentation processes) the activation of the so-called "cryptic clusters" in microbes. Just as in the human genome, the full epigenetic control mechanisms have not been elucidated in any microbe. Yes, we do know some of the parameters required in certain biosynthetic clusters, but how much of the total genome of a microbe is composed of control mechanisms is unknown.

There are relatively simple methods and more complex ones that can be used to "unlock" the Pandora's box that any genome represents. The modification of genetic control elements in Aspergillus, as published by Bok et al. in $2006^{57}$, is one route, but the use of exogenous chemicals such as DNA methylators or histone acetylation modifiers are simpler examples, with some excellent work demonstrating such possibilities emanating from the Cichewicz group in $2008^{74}$ and expanded in following years ${ }^{75-78}$.

In addition to the "epigenetic modulators" listed above, the use of simple antibiotics in a single microbial fermentation can lead to the production of previously unknown metabolites. Thus, Truong et al. demonstrated that if Burkholderia thailandensis is treated with the well-known antibiotic trimethoprim, the activation of an orphan LuxR homolog known as MalR occurs, which is linked to the gene cluster that yields the toxic polyketide malleilactone ${ }^{79}$. This sublethal trimethoprim- $B$. thailandensis combination was then later shown to induce the production of over 100 compounds previously not known from this particular microbe ${ }^{80}$. In order to identify these materials, the investigators used the mass spectral networking technique pioneered by the Dorrestein group ${ }^{70,81}$. A very recent paper from the same group then identified the master regulator Scmr (secondary metabolite regulator) for the production of secondary metabolites in the same bacterium. Removal of this regulator then led to overproduction of some secondary metabolites by more than 200 -fold ${ }^{82}$.

However, there is another simple process that can be applied to the screening of microbes for epigenetic-induced amplification of genetic clusters and/or modified metabolites. This is to simply grow two or more microbes in the presence of each other. This is often thought to be a relatively new concept but in fact was being investigated in the pharmaceutical industry in the 1970s using a device known as the EcoLogen, which was effectively four vessels arranged around a central chamber that could be individually closed with solid gates or selective filters. One microbe in the center could be influenced by chemical entities, well before any knowledge of quorum sensors, as the operator desired. There are only three academic references to the use of this device ${ }^{83-85}$, but the author used it quite extensively in industry in the late 1970s. However, results were difficult to interpret at times because of the lack of sensitive analytical systems 30-plus years ago. 
However, today, there are multiple reports of novel agents coming from mixed culture techniques, with perhaps the first one showing a novel bioactive product being the report from the Fenical group at the Scripps Oceanographic Institution in 2001 of pestalone. This metabolite arose from challenging the marine-derived fungus Pestalotia spp. with a marine $\alpha$-proteobacterium ${ }^{86}$, which was followed 4 years later by the report of the marine-derived fungus Libertella spp. yielding new cytotoxic diterpenoids, libertellenones A-D, when co-fermented with the same $\alpha$-proteobacterium ${ }^{87}$. Later work from the same group, but using the marine-sourced fungus Emericella spp. and culturing with the obligate marine bacterium Salinispora arenicola, produced the cyclic depsipeptides known as emericellamides $\mathrm{A}$ and $\mathrm{B}^{88}$.

In 2014, the Wolfender group published an excellent paper on the methodology for studying microbial interactions in 12 -well plates. This mimicked, to some extent, methods used many years ago in industry for the production of novel antibiotics, where one microbe was grown on an agar slant then a liquid culture of another microbe or supplemented medium was added and the presence of induced activity was checked against suitable test microbes. The Wolfender group used modern analytical techniques to demonstrate the production of novel metabolites from this process ${ }^{89}$. A very interesting variation on the same theme is the one recently published by Barkal et al., where microfluidic techniques are used followed by untargeted metabolomics ${ }^{90}$.

Thus, one might well state that old techniques often used in the 1960s and 1970s when pharmaceutical houses were the major sources of natural product-derived drug candidates have now met up with modern analytical systems. Unfortunately, except for an occasional patent or publication well after the programs had been shut down, only the memories of the scientists involved are left, as publication was not encouraged and, frequently at that time, the methodologies were proprietary.

\section{Conclusion}

Is there hope for interesting molecules to come from these multiplex types of screening systems?

From the examples that have been given above, the interplay of very talented academic scientists with state-of-the-art analytical systems bodes well for finding novel agents from (mainly) microbial sources, even though frequently the nominal starting source is not a microbe. As shown in the case of the sponge metabolites from Theonella swinhoei $\mathrm{Y}$, the complex molecules produced have significant activity and their structures are ones that no synthetic chemist would ever conceive in the absence of a similar compound. In addition, until that work was reported, the investigation of as-yetuncultivated microbes from a metabolome aspect was a problem few scientists would even "touch". Currently, that specific paper" from 2014 has over 150 citations in the Scopus database at the time of writing. In addition, the recent paper from the Piel group should also be required reading for scientists interested in the potential of this type of technology ${ }^{11}$.

What is also of import is the realization that in addition to the discovery that significant numbers of marine-sourced agents have a microbe in their background, important bioactive plant-derived compounds such as the taxanes, camptothecins, and vinca alkaloids have endophytic microbes in their "background", and in the case of maytansine, there is no doubt that the molecule is bacterial in origin $^{91}$.

The "systems integration" demonstrated above also bodes well for investigations of the enormous potential of both terrestrial and marine microbes and their associated "hosts". The oceans cover $70 \%$ of the Earth's surface and numbers of microbes per $\mathrm{cm}^{3}$ of seawater alone run between $10^{3}$ and $10^{5}$. It should be remembered that a suspension of $10^{5} \mathrm{E}$. coli per $\mathrm{mL}\left(1 \mathrm{~cm}^{3}\right)$ is a clear solution to the human eye. When one also considers that $\sim 50 \%$ wet weight of a sponge is composed of single-celled organisms (not all eubacteria or fungi), the numbers of potential sources are incalculable if one also includes the microbial content of the seabed. Some relevant recent examples will give an idea of the potential.

In the marine area, the Fenical group and collaborators at the Scripps Oceanographic Institution in San Diego have published extensively on the potential of marine microbes, usually freeliving but at times associated with invertebrates. The examples given earlier on products from co-culture are one aspect; in addition, papers from long-time collaborators Jensen and Moore, and later Dorrestein, give further insight into the vast areas that still have to be investigated ${ }^{24,25,92-94}$. These investigations, when coupled to the methodologies reported by the Piel group on marinesourced but as-yet-uncultivated microbes (see earlier section), demonstrate the potential of these sources to uncover novel agents that may result from using the "modernized grind and find" and coupling to the latest phenotypic screening techniques.

Finally, one could even postulate that "all that is old is new again" in this field, as older concepts and some early reports of potential novel agents in strange places have now met up with the necessary tools to investigate these areas.

\section{Abbreviations}

HPLC, high-performance liquid chromatography (early versions had "pressure" instead of "performance"); IMS, imaging mass spectroscopy; LLE, lead-like enhanced; $\mathrm{MS}^{\mathrm{n}}$; mass spectroscopy (the superscript is a number and means that various further MS fragmentation patterns can be analysed); NMR, nuclear magnetic resonance.

\section{Author contributions}

David J Newman retired in January 2015 from the position of Chief of the Natural Products Branch at the National Cancer Institute $\mathrm{NIH}$, in Frederick, Maryland USA.

\section{Competing interests}

The author declares that he has no competing interests.

\section{Grant information}

The author(s) declared that no grants were involved in supporting this work.

\section{Acknowledgements}

Old colleagues in the then SK\&F microbiology department, and later colleagues in the US pharmaceutical industry and the US National Cancer Institute. 
1. Newman DJ, Cragg GM: Natural Products as Sources of New Drugs from 1981 to 2014. J Nat Prod. 2016; 79(3): 629-61. PubMed Abstract | Publisher Full Text

2. Rask-Andersen M, Zhang J, Fabbro D, et al:: Advances in kinase targeting: current clinical use and clinical trials. Trends Pharmacol Sci. 2014; 35(11): $604-20$.

PubMed Abstract | Publisher Full Tex

3. F Fabbro D, Cowan-Jacob SW, Moebitz H: Ten things you should know about protein kinases: IUPHAR Review 14. Br J Pharmacol. 2015; 172(11): 2675-700. PubMed Abstract | Publisher Full Text | Free Full Text | F1000 Recommendation

4. $\quad F$ Lin A, Giuliano CJ, Sayles NM, et al.: CRISPR/Cas9 mutagenesis invalidates a putative cancer dependency targeted in on-going clinical trials. eLife. 2017; 6: pii: e24179.

PubMed Abstract | Publisher Full Text | Free Full Text | F1000 Recommendation

5. Moffat JG, Rudolph J, Bailey D: Phenotypic screening in cancer drug discovery - past, present and future. Nat Rev Drug Discov. 2014; 13(8): 588-602.

PubMed Abstract | Publisher Full Text

6. Swinney DC, Anthony J: How were new medicines discovered? Nat Rev Drug Discov. 2011: 10(7): 507-19.

PubMed Abstract | Publisher Full Text

7. Newman DJ: The Influence of Brazilian Biodiversity on Searching for Human Use Pharmaceuticals. J Braz Chem Soc. 2016.

Publisher Full Text

8. Nakamura K, lizuka R, Nishi S, et al:: Culture-independent method for identification of microbial enzyme-encoding genes by activity-based single-cell sequencing using a water-in-oil microdroplet platform. Sci Rep. 2016; 6: 22259. PubMed Abstract | Publisher Full Text | Free Full Text

9. F Wilson MC, Mori T, Ruckert C, et al.: An environmental bacterial taxon with a large and distinct metabolic repertoire. Nature. 2014; 506(7486): 58-62. PubMed Abstract | Publisher Full Text | F1000 Recommendation

10. F Freeman MF, Vagstad AL, Piel J: Polytheonamide biosynthesis showcasing the metabolic potential of sponge-associated uncultivated 'Entotheonella' bacteria. Curr Opin Chem Biol. 2016; 31: 8-14. PubMed Abstract | Publisher Full Text | F1000 Recommendation

11. F Lackner G, Peters EE, Helfrich EJ, et al.: Insights into the lifestyle of uncultured bacterial natural product factories associated with marine sponges. Proc Natl Acad Sci U S A. 2017; 114(3): E347-E356. PubMed Abstract | Publisher Full Text | Free Full Text | F1000 Recommendation

12. Munro MH, Blunt JW, Dumdei EJ, et al:: The discovery and development of marine compounds with pharmaceutical potential. J Biotechnol. 1999; 70(1-3) $15-25$.

PubMed Abstract | Publisher Full Text

13. Esquenazi E, Yang YL, Watrous J, et al:: Imaging mass spectrometry of natural products. Nat Prod Rep. 2009; 26(12): 1521-34. PubMed Abstract | Publisher Full Text

14. Watrous JD, Dorrestein PC: Imaging mass spectrometry in microbiology. Nat Rev Microbiol. 2011; 9(9): 683-94.

PubMed Abstract | Publisher Full Text | Free Full Text

15. Watrous JD, Alexandrov T, Dorrestein PC: The evolving field of imaging mass spectrometry and its impact on future biological research. J Mass Spectrom. 2011; 46(2): 209-22.

PubMed Abstract | Publisher Full Text | Free Full Text

16. $\mathrm{F} X u \mathrm{Y}$, Kersten RD, Nam SJ, et al.: Bacterial biosynthesis and maturation of the didemnin anti-cancer agents. J Am Chem Soc. 2012; 134(20): 8625-32. PubMed Abstract | Publisher Full Text | Free Full Text | F1000 Recommendation

17. Tsukimoto $M$, Nagaoka $M$, Shishido $Y$, et al.: Bacterial production of the tunicate derived antitumor cyclic depsipeptide didemnin B. J Nat Prod. 2011; 74(11): 2329-31.

PubMed Abstract | Publisher Full Tex

18. F Doroghazi JR, Albright JC, Goering AW, et al.: A roadmap for natural product discovery based on large-scale genomics and metabolomics. Nat Chem Biol. 2014; 10(11): 963-8.

PubMed Abstract | Publisher Full Text | Free Full Text | F1000 Recommendation

19. F Henke MT, Kelleher NL: Modern mass spectrometry for synthetic biology and structure-based discovery of natural products. Nat Prod Rep. 2016; 33(8): $942-50$.

PubMed Abstract | Publisher Full Text | Free Full Text | F1000 Recommendation

20. Choi S, Kim H, Lee H, et al:: Genome mining of rare actinomycetes and cryptic pathway awakening. Process Biochemistry. 2015; 50(8): 1184-93. Publisher Full Text

21. Keller NP: Translating biosynthetic gene clusters into fungal armor and weaponry. Nat Chem Biol. 2015; 11(9): 671-7. PubMed Abstract | Publisher Full Text | Free Full Text
22. F Kleigrewe K, Almaliti J, Tian IY, et al:: Combining Mass Spectrometric Metabolic Profiling with Genomic Analysis: A Powerful Approach for Discovering Natural Products from Cyanobacteria. J Nat Prod. 2015; 78(7): 1671-82.

PubMed Abstract | Publisher Full Text | Free Full Text | F1000 Recommendation

23. Cuperlovic-Culf M, Culf AS: Applied metabolomics in drug discovery. Expert Opin Drug Discov. 2016; 11(8): 759-70. PubMed Abstract | Publisher Full Text

24. Floros DJ, Jensen PR, Dorrestein PC, et al:: A metabolomics guided exploration of marine natural product chemical space. Metabolomics. 2016; 12: 145. Publisher Full Text

25. Jensen PR: Natural Products and the Gene Cluster Revolution. Trends Microbiol. 2016; 24(12): 968-77.

PubMed Abstract | Publisher Full Text | Free Full Text

26. Adamek M, Spohn M, Stegmann E, et al:: Mining bacterial genomes for secondary metabolite gene clusters. In Antibiotics: Methods and Protocols. Methods Mol Biol. Sass P, Ed., Springer Science+Business Media: New York, 2017 1520: 23-47.

PubMed Abstract | Publisher Full Text

27. Allard PM, Genta-Jouve G, Wolfender JL: Deep metabolome annotation in natural products research: towards a virtuous cycle in metabolite identification. Curr Opin Chem Biol. 2017; 36: 40-9. PubMed Abstract | Publisher Full Text

28. Covington BC, McLean JA, Bachmann BO: Comparative mass spectrometrybased metabolomics strategies for the investigation of microbial secondary metabolites. Nat Prod Rep. 2017; 34(1): 6-24.

PubMed Abstract | Publisher Full Text | Free Full Text

29. Lamb J: The Connectivity Map: a new tool for biomedical research. Nat Rev Cancer. 2007; 7(1): 54-60. PubMled Abstract | Publisher Full Tex

30. F Vaden RM, Oswald NW, Potts MB, et al.: FUSION-Guided Hypothesis Development Leads to the Identification of $N^{6}, N^{6}$-Dimethyladenosine, a MarineDerived AKT Pathway Inhibitor. Mar Drugs. 2017; 15(3): pii: E75.

PubMed Abstract | Publisher Full Text | Free Full Text | F1000 Recommendation

31. Hassig CA, Zeng FY, Kung P, et al:: Ultra-High-Throughput Screening of Natural Product Extracts to Identify Proapoptotic Inhibitors of Bcl-2 Family Proteins. J Biomol Screen. 2014; 19(8): 1201-11.

PubMed Abstract | Publisher Full Text | Free Full Text

32. Hiraki M, Hwang SY, Cao S, et al:: Small-Molecule Reactivation of Mutant p53 to Wild-Type-like p53 through the p53-Hsp40 Regulatory Axis. Chem Biol. 2015; 22(9): 1206-16.

PubMed Abstract | Publisher Full Text | Free Full Text

33. Vafai SB, Mevers E, Higgins KW, et al:: Natural Product Screening Reveals Naphthoquinone Complex I Bypass Factors. PLoS One. 2016; 11(9): e0162686. PubMed Abstract | Publisher Full Text | Free Full Text

34. Schiewe $\mathrm{HJ}$, Zeeck A: Cineromycins, gamma-butyrolactones and ansamycins by analysis of the secondary metabolite pattern created by a single strain of Streptomyces. J Antibiot (Tokyo). 1999; 52(7): 635-42. PubMed Abstract | Publisher Full Text

35. Zähner H: Some aspects of antibiotics research. Angew Chem Int Ed Engl. 1977; 16(10): 687-94. PubMed Abstract | Publisher Full Tex

36. F Schmid I I, Sattler I I, Grabley S, et al.: Natural Products in High Throughput Screening: Automated High-Quality Sample Preparation. J Biomol Screen. 1999; 4(1): 15-25

PubMed Abstract | Publisher Full Text | F1000 Recommendation

37. Eldridge GR, Vervoort HC, Lee CM, et al:: High-throughput method for the production and analysis of large natural product libraries for drug discovery. Anal Chem. 2002; 74(16): 3963-71.

PubMed Abstract | Publisher Full Text

38. Abel U, Koch $\mathrm{C}$, Speitling M, et al.: Modern methods to produce natural-product libraries. Curr Opin Chem Biol. 2002; 6(4): 453-8. PubMed Abstract | Publisher Full Text

39. Appleton DR, Buss AD, Butler MS: A Simple Method for High-Throughput Extract Prefractionation for Biological Screening. CHIMIA. 2007; 61(6): 327-31. Publisher Full Text

40. Wagenaar MM: Pre-fractionated microbial samples--the second generation natural products library at Wyeth. Molecules. 2008; 13(6): 1406-26. PubMed Abstract | Publisher Full Text

41. Bugni TS, Richards B, Bhoite L, et al:: Marine natural product libraries for high-throughput screening and rapid drug discovery. J Nat Prod. 2008; 71(6): 1095-8.

PubMed Abstract | Publisher Full Text | Free Full Text

42. Hou $Y$, Braun DR, Michel $C R$, et al.: Microbial strain prioritization using 
metabolomics tools for the discovery of natural products. Anal Chem. 2012 84(10): 4277-83.

PubMed Abstract | Publisher Full Text | Free Full Text

43. Camp D, Campitelli M, Carroll AR, et al.: Front-loading natural-product-screening libraries for $\log P$ : background, development, and implementation. Chem Biodivers. 2013; 10(4): 524-37.

PubMed Abstract | Publisher Full Text

44. Henrich CJ, Beutler JA: Matching the power of high throughput screening to the chemical diversity of natural products. Nat Prod Rep. 2013; 30(10): 1284-98. PubMed Abstract | Publisher Full Text | Free Full Text

45. Adnani N, Ellis GA, Wyche TP, et al.: Emerging trends for stimulating the discovery of natural products. In Natural Products Analysis: Instrumentation, Methods and Applications, Havlíček V; Spížek J, Eds. John Wiley \& Sons Inc: New York, 2014; 115-161.

Publisher Full Text

46. Butler MS, Fontaine F, Cooper MA: Natural product libraries: assembly, maintenance, and screening. Planta Med. 2014; 80(14): 1161-70. PubMed Abstract | Publisher Full Text

47. Fenner AM, Gerwick WH: Marine Bioprospecting. In Natural Product: Discourse, Diversity and Design, Osbourn A.; Goss RJ; Carter GT, Eds. Wiley Blackwell: Oxford UK. 2014; 85-101.

Publisher Full Text

48. F Gaudêncio SP, Pereira F: Dereplication: racing to speed up the natural products discovery process. Nat Prod Rep. 2015; 32(6): 779-810. PubMed Abstract | Publisher Full Text | F1000 Recommendation

49. Schlotterbeck $\mathrm{G}$, Pasch $\mathrm{H}$, Albert $\mathrm{K}$ : On-line HPLC ${ }^{1} \mathrm{H}$ NMR coupling for the analysis of fatty alcohol ethoxylates. Polym Bull. 1997; 38(6): 673-9. Publisher Full Text

50. Romero CA, Grkovic T, Han J, et al:: NMR fingerprints, an integrated approach to uncover the unique components of the drug-like natural product metabolome of termite gut-associated Streptomyces species. RSC Adv. 2015: 5: 104524-34 Publisher Full Text

51. F Wang D, Feng Y, Murtaza M, et al:: A Grand Challenge: Unbiased Phenotypic Function of Metabolites from Jaspis splendens against Parkinson's Disease. J Nat Prod. 2016; 79(2): 353-61.

PubMed Abstract | Publisher Full Text | F1000 Recommendation

52. F Vial ML, Zencak D, Grkovic T, et al.: A Grand Challenge. 2. Phenotypic Profiling of a Natural Product Library on Parkinson's Patient-Derived Cells. J Nat Prod. 2016; 79(8): 1982-9.

PubMed Abstract | Publisher Full Text | F1000 Recommendation

53. F Fetz V, Prochnow $\mathrm{H}$, Bronstrup $\mathrm{M}$, et al.: Target identification by image analysis. Nat Prod Rep. 2016; 33(5): 655-67. PubMed Abstract | Publisher Full Text | F1000 Recommendation

54. F Kurita KL, Linington RG: Connecting phenotype and chemotype: High-content discovery strategies for natural products research. J Nat Prod. 2015; 78(3): 587-96

PubMed Abstract | Publisher Full Text | F1000 Recommendation

55. F Kurita KL, Glassey E, Linington RG: Integration of high-content screening and untargeted metabolomics for comprehensive functional annotation of natural product libraries. Proc Natl Acad Sci U S A. 2015; 112(39): 11999-2004. PubMed Abstract | Publisher Full Text | Free Full Text | F1000 Recommendation

56. Guo CJ, Wang CC: Recent advances in genome mining of secondary metabolites in Aspergillus terreus. Front Microbiol. 2014; 5: 717 PubMed Abstract | Publisher Full Text | Free Full Text

57. F Bok JW, Hoffmeister D, Maggio-Hall LA, et al:: Genomic mining for Aspergillus natural products. Chem Biol. 2006; 13(1): 31-7. PubMed Abstract | Publisher Full Text | F1000 Recommendation

58. F Wiemann P, Keller NP: Strategies for mining fungal natural products. J Ind Microbiol Biotechnol. 2014; 41(2): 301-13.

PubMed Abstract | Publisher Full Text | F1000 Recommendation

59. Bignell E, Cairns TC, Throckmorton K, et al:: Secondary metabolite arsenal of an opportunistic pathogenic fungus. Philos Trans R Soc Lond B Biol Sci. 2016; 371(1709): pii: 20160023.

PubMed Abstract | Publisher Full Text | Free Full Text

60. Henke MT, Soukup AA, Goering AW, et al:: New Aspercryptins, Lipopeptide Natural Products, Revealed by HDAC Inhibition in Aspergillus nidulans. ACS Chem Biol. 2016; 11(8): 2117-23.

PubMed Abstract | Publisher Full Text | Free Full Text

61. Plaza A, Müller R: Myxobacteria: Chemical diversity and screening strategies. In Natural Products: Discourse, Diversity, and Design, Osbourn A, Goss RJ, Carter GT. John Wiley \& Sons IPb, Eds. John Wiley \& Sons, Inc: Hoboken NJ. 2014; 103-124.

Publisher Full Text

62. F Zaburannyi N, Bunk B, Maier J, et al: Genome Analysis of the Fruiting BodyForming Myxobacterium Chondromyces crocatus Reveals High Potential for Natural Product Biosynthesis. Appl Environ Microbiol. 2016; 82(6): 1945-57. Natural Product Biosynthesis. Appl Environ Microbiol. 2016; 82(6): 1945-57.
PubMed Abstract | Publisher Full Text | Free Full Text | F1000 Recommendation

63. F Meusel M, Hufsky F, Panter F, et al:: Predicting the Presence of Uncommon
Elements in Unknown Biomolecules from Isotope Patterns. Anal Chem. 2016; 88(15): 7556-66.

PubMed Abstract | Publisher Full Text | F1000 Recommendation

64. F Herrmann J, Fayad AA, Müller R: Natural products from myxobacteria: nove metabolites and bioactivities. Nat Prod Rep. 2017; 34(2): 135-60. PubMed Abstract | Publisher Full Text | F1000 Recommendation

65. F Wenzel SC, Hoffmann H, Zhang J, et al:: Production of the Bengamide Class of Marine Natural Products in Myxobacteria: Biosynthesis and StructureActivity Relationships. Angew Chem Int Ed Engl. 2015; 54(51): 15560-4. PubMed Abstract | Publisher Full Text | F1000 Recommendation

66. Hoffmann H, Haag-Richter S, Kurz M, et al.: Bengamide derivatives, method for the production thereof and use thereof for the treatment of cancer. WO/2005/044803, Filing date 24OCT2003; Publication date 19MAY2005. Reference Source

67. Johnson TA, Sohn J, Vaske YM, et al.: Myxobacteria versus sponge-derived alkaloids: the bengamide family identified as potent immune modulating agents by scrutiny of LC-MS/ELSD libraries. Bioorg Med Chem. 2012; 20(14) 4348-55.

PubMed Abstract | Publisher Full Text | Free Full Text

68. F Hoffmann T, Müller S, Nadmid S, et al.: Microsclerodermins from terrestrial myxobacteria: an intriguing biosynthesis likely connected to a sponge symbiont. J Am Chem Soc. 2013; 135(45): 16904-11.

PubMed Abstract | Publisher Full Text | F1000 Recommendation

69. Petras D, Jarmusch AK, Dorrestein PC: From single cells to our planet-recent advances in using mass spectrometry for spatially resolved metabolomics. Curr Opin Chem Biol. 2017; 36: 24-31.

PubMed Abstract | Publisher Full Tex

70. Quinn RA, Nothias LF, Vining O, et al.: Molecular Networking As a Drug Discovery, Drug Metabolism, and Precision Medicine Strategy. Trends Pharmacol Sci. 2017; 38(2): 143-54. PubMed Abstract | Publisher Full Text

71. F Humbeck L, Koch O: What Can We Learn from Bioactivity Data? Chemoinformatics Tools and Applications in Chemical Biology Research. ACS Chem Biol. 2017; 12(1): 23-35

PubMed Abstract | Publisher Full Text | F1000 Recommendation

72. F González-Medina M, Prieto-Martinez FD, Naveja JJ, et al:: Chemoinformatic expedition of the chemical space of fungal products. Future Med Chem. 2016 8(12): 1399-412.

PubMed Abstract | Publisher Full Text | F1000 Recommendation

73. $\quad F$ Kellogg JJ, Todd DA, Egan JM, et al.: Biochemometrics for Natural Products Research: Comparison of Data Analysis Approaches and Application to Identification of Bioactive Compounds. J Nat Prod. 2016; 79(2): 376-86. PubMed Abstract | Publisher Full Text | Free Full Text | F1000 Recommendation

74. F Williams RB, Henrikson JC, Hoover AR, et al:: Epigenetic remodeling of the fungal secondary metabolome. Org Biomol Chem. 2008; 6(11): 1895-7. PubMed Abstract | Publisher Full Text | F1000 Recommendation

75. Fisch KM, Gillaspy AF, Gipson M, et al:: Chemical induction of silent biosynthetic pathway transcription in Aspergillus niger. $J$ Ind Microbiol Biotechnol. 2009; 36(9): 1199-213.

PubMed Abstract | Publisher Full Text

76. Henrikson JC, Hoover AR, Joyner PM, et al.: A chemical epigenetics approach for engineering the in situ biosynthesis of a cryptic natural product from Aspergillus niger. Org Biomol Chem. 2009; 7(3): 435-8. PubMled Abstract | Publisher Full Text

77. Cichewicz RH: Epigenome manipulation as a pathway to new natural product scaffolds and their congeners. Nat Prod Rep. 2010; 27(1): 11-22. PubMed Abstract | Publisher Full Text | Free Full Text

78. Cichewicz RH, Henrikson JC, Wang $X$, et al: Strategies for accessing microbial secondary metabolites from silent biosynthetic pathways. In Manual of Industrial Microbiology and Biotechnology, 3rd ed. Baltz RH, Demain AL, Davies JE, Eds. ASM Press: Washington D.C, 2010; 78-95. Publisher Full Text

79. F Truong TT, Seyedsayamdost M, Greenberg EP, et al.: A Burkholderia thailandensis Acyl-Homoserine Lactone-Independent Orphan LuxR Homolog That Activates Production of the Cytotoxin Malleilactone. J Bacteriol. 2015; 197(21): 3456-62.

PubMed Abstract | Publisher Full Text | Free Full Text | F1000 Recommendation

80. F Okada BK, Wu Y, Mao D, et al:: Mapping the Trimethoprim-Induced Secondary Metabolome of Burkholderia thailandensis. ACS Chem Biol. 2016; 11(8): 2124-30.

PubMed Abstract | Publisher Full Text | F1000 Recommendation

81. F Watrous J, Roach P, Alexandrov T, et al:: Mass spectral molecular networking of living microbial colonies. Proc Natl Acad Sci U S A. 2012; 109(26) E1743-52.

PubMed Abstract | Publisher Full Text | Free Full Text | F1000 Recommendation

82. $\mathrm{F}$ Mao D, Bushin LB, Moon $\mathrm{K}$, et al:: Discovery of scmR as a global regulator of secondary metabolism and virulence in Burkholderia thailandensis E264. Proc Natl Acad Sci U S A. 2017; 114(14): E2920-E2928.

PubMed Abstract | Publisher Full Text | Free Full Text | F1000 Recommendation 
83. Martin DF, Kutt EC, Kim YS: Use of a Multiple Diffusion Chamber Unit in Culture Studies. Application to Gomphosphaeria Aponina. Environ Lett. 2009; 7(1): 39-46. Publisher Full Text

84. Lebrun M, de Repentigny J, Mathieu LG: [Diminution of the antibacterial activity of antibiotics in cultures and in experimental mixed infections]. Can J Microbiol. 1978; 24(2): 154-61. PubMed Abstract

85. Martin BB, Martin DF: Use of the EcoloGen to study Hydrilla growth inhibitors. $J$ Aquat Plant Manage. 1986; 24: 82-84. Reference Source

86. F Cueto M, Jensen PR, Kauffman C, et al:: Pestalone, a new antibiotic produced by a marine fungus in response to bacterial challenge. $J$ Nat Prod. 2001; 64(11): 1444-6.

PubMed Abstract | Publisher Full Text | F1000 Recommendation

87. Oh DC, Jensen PR, Kauffman CA, et al.: Libertellenones A-D: induction of cytotoxic diterpenoid biosynthesis by marine microbial competition. Bioorg Med Chem. 2005; 13(17): 5267-73. PubMed Abstract | Publisher Full Text

88. Oh DC, Kauffman CA, Jensen PR, et al.: Induced production of emericellamides $A$ and $B$ from the marine-derived fungus Emericella sp. in competing co-culture. J Nat Prod. 2007; 70(4): 515-20.

PubMed Abstract | Publisher Full Text
89. Bertrand S, Azzollini A, Schumpp O, et al.: Multi-well fungal co-culture for de novo metabolite-induction in time-series studies based on untargeted metabolomics. Mol Biosyst. 2014; 10(9): 2289-98.

PubMed Abstract | Publisher Full Text

90. Barkal LJ, Theberge AB, Guo CJ, et al.: Microbial metabolomics in open microscale platforms. Nat Commun. 2016; 7: 10610. PubMed Abstract | Publisher Full Text | Free Full Text

91. Newman DJ, Cragg GM: Endophytic and epiphytic microbes as "sources" of bioactive agents. Front Chem. 2015; 3: 34

PubMed Abstract | Publisher Full Text | Free Full Text

92. Schorn MA, Alanjary MM, Aguinaldo $\mathrm{K}$, et al.: Sequencing rare marine actinomycete genomes reveals high density of unique natural product biosynthetic gene clusters. Microbiology. 2016; 162(12): 2075-86. PubMed Abstract | Publisher Full Text

93. Patin NV, Schorn M, Aguinaldo K, et al.: Effects of Actinomycete Secondary Metabolites on Sediment Microbial Communities. Appl Environ Microbiol. 2017; 83(4): pii: e02676-16.

PubMed Abstract | Publisher Full Text | Free Full Text

94. Crüsemann M, O'Neill EC, Larson CB, et al.: Prioritizing Natural Product Diversity in a Collection of 146 Bacterial Strains Based on Growth and Extraction Protocols. J Nat Prod. 2017; 80(3): 588-97. PubMed Abstract | Publisher Full Text | Free Full Text 


\section{Open Peer Review}

\section{Current Peer Review Status:}

\section{Editorial Note on the Review Process}

Faculty Reviews are review articles written by the prestigious Members of Faculty Opinions. The articles are commissioned and peer reviewed before publication to ensure that the final, published version is comprehensive and accessible. The reviewers who approved the final version are listed with their names and affiliations.

\section{The reviewers who approved this article are:}

\section{Version 1}

\section{Rolf Müller}

Helmholtz Centre for Infection Research and Department of Pharmaceutical Biotechnology, Saarland University, Saarbrücken, Germany

Competing Interests: No competing interests were disclosed.

\section{Roger G. Linington}

Department of Chemistry and Biochemistry, University of California, Santa Cruz, CA, USA

Competing Interests: No competing interests were disclosed.

The benefits of publishing with F1000Research:

- Your article is published within days, with no editorial bias

- You can publish traditional articles, null/negative results, case reports, data notes and more

- The peer review process is transparent and collaborative

- Your article is indexed in PubMed after passing peer review

- Dedicated customer support at every stage

For pre-submission enquiries, contact research@f1000.com 